\title{
Deity, love, punishment, rage, and mythonyms from head to toes. A brief history of some medical terms
}

\author{
Adrian Naznean* \\ Department 1 of Science and Letters, George Emil Palade University of Medicine, Pharmacy, \\ Science, and Technology of Targu Mures, Romania
}

\begin{abstract}
Although it is undoubtful that today's Medical English is rooted in Greek and Latin, it is particularly interesting that figures from Greek mythology are the roots of words to describe conditions, body parts, feelings, substances, etc. While there are numerous medical terms that are derived from the names of Greek mythological figures, this paper will only investigate words ranging from $A$ to $H$ and will try to justify the relationship between the concepts and the choice of terminology.
\end{abstract}

Keywords: deity, gods, goddesses, Greek mythology, medical mythonymy

Received: 25 th June 2021; Accepted: $7^{\text {th }}$ July 2021; Published: $9^{\text {th }}$ July 2021

\section{Introduction}

Storytelling is an important part of every culture. It functions as lessons and examples to be followed, it instils various moral and ethical values within a community. But because these lessons are handed down by word of mouth, they oftentimes become embellished, distorted, or augmented by many details. Whenever one turns to Greek myths, they will get the eternal and endlessly entertaining feeling of the stories. The world of Greek mythology brings onto page hundreds of characters: immortals, heroes, villains, mortals, titans, or hideous creatures come to life in the stories of Homer or Hesiod. An additional value which ensures the survival of mythological elements is brought about by their visual interpretation on various objects such as amphorae, sculptures, statues, etc. While the stories depict imaginary situations and events, what is particularly intriguing is the impact they had on language.

\section{Mythonyms rooted in Greek mythology}

Achilles, the greatest warrior of all Greek myth and the son of Thetis and Peleus, was named such by Chiron because the child had never been breastfed. Etymologically, the name of Achilles is the combination of the privative $a$ - and cheilos, meaning lips, thus, the one without lips (1). His mother, the sea nymph Thetis, wanting to

\footnotetext{
* Corresponding author: Adrian Naznean, Department 1 of Science and Letters, George Emil Palade University of Medicine, Pharmacy, Science, and Technology of Targu Mures, Romania. E-mail: adrian.naznean@umfst.ro
} 
make her son immortal, dipped him into the river Styx. The heel from which the mother held him was the only vulnerable point of his body, and the target of Paris's poisoned arrow which killed him. The name of the mythological figure is associated with several anatomical parts and conditions: Achille's heel, Achille's tendon, Achille's rupture, Achille's region, Achille's tendinitis, or Achille's tendinopathy.

Aphrodite, one of the most famous goddesses of Greek mythology, was renowned for her unmatched beauty and her ability to arouse sexual desire. She was born from foam when the severed genitals of Ouranus (Uranus) fell into the sea. According to some legends, she arrived at Cythera, but floated on to reach Cyprus. According to Homer, Aphrodite was the daughter of Zeus and Dione. In Plato's view, there were two Aphrodites, a heavenly one, the one born from the sea, and an earthly one, the daughter of Zeus and Dione. Nevertheless, the goddess of love and the embodiment of desire, had multiple love affairs with both gods and Anchises. Probably it is no surprise that her name is the root for aphrodisiac to denote a food or drug that arouses sexual instinct and increases pleasure. The word has an antonym, that is anaphrodisiac. The veil of Aphrodite is the superficial membrane on the anterolateral surface of the prostate gland (2). Moreover, Aphrodite is also responsible for the term hermaphrodite which will be detailed later on.

Although not a goddess, Arachne was the daughter of Idmon of Colophon. She was an expert weaver who committed suicide following the competition with Athena because the goddess of war and many crafts and skills tore her perfect tapestry refusing to admit to Arachne's superiority and to lose. Athena changed Arachne's rope into a cobweb and Arachne into a spider, an insect which the goddess despised. Arachne is represented in medical terminology as arachnoid to refer to a thin membrane of the brain and spinal cord that lies between the dura mater and the pia mater. Undoubtedly, her name is the root for other words as well such as: arachnid, arachnidium, arachnoiditis, arachnology, Arachnomorphae, arachnophobia, to name a few.

The Titan Atlas, the brother of Prometheus among others, was the son of Iapetus and Clymene (3). He was a second-generation Titan and one of the generals in the war against the Olympians which the Titans lost. Consequently, Atlas was punished to stand at the western end of the Earth and hold up the sky. In his attempt to get the golden apples form the Hesperides, Heracles, who was cautioned not to pick the apples himself, relied on the help of Atlas convincing him to hold the sky while Atlas would pick the apple. After getting the apple, Atlas was reluctant to return to his duty as the holder of the sky, but Heracles fooled him once more pretending to place a cushion on his shoulders to ease the burden and making his getaway. It may be due to the position of the sky resting on the back of the Titan's neck that atlas came to mean the first vertebra of the neck. It may or may not be hazardous that the same term atlas denotes a collection of maps or a male figure used like a caryatid as a supporting column or pilaster to symbolise the heavy burden of holding the upper, and probably, most important part.

Chimera was a monstrous-looking beast with the head and body of a goat, the legs of a lion, and had a snake as the tail. The beast wreaked havoc in Lycia, Asia Minor, and King Iobates sought a hero to destroy the monster. Bellerophon, the son of Glaucus, king of Corinth, was very skilled with weaponry and was commissioned by Iobates to kill the monster. In order to help him, Poseidon, who was rumoured to be Bellerophon's actual father, offered his winged-horse, Pegasus. The lead arrow that the handsome and brave warrior shot in the mouth of the beast was melted by the flaming breath of Chimera and burnt the body of the monster (4). While in common language 
the adjective chimeric, or chimerical, means visionary, fantastic, unreal, or wildly improbable, in medical terminology it refers to an organism composed of cells from two or more different zygotes. $(5,6)$. It is also used in phrases such as chimeric antigen-receptor-modified T cells, chimeric mouse, or chimeric antibody.

While few medical professionals wound wonder about the origin of a word they use on a daily basis, the adjective chronic is rooted in mythology. Cronus (Kronos) was the Titan who emasculated his father (7), Ouranos (Uranus), and was also notorious for swallowing his own children with Rhea, daughter of Ouranos and his own sister. He was the son of Ouranos and Gaia and according to a prophecy he was to be overthrown by one of his own children. In order to save one of them, Rhea handed Cronus a stone wrapped in cloth to swallow, and the child, none else but Zeus, was thus saved and brought up on the island of Crete. Zeus had grown into a powerful god and with the help of his mother he made Cronus vomit the swallowed children. Thus, Poseidon, Hades, Hera, Demeter, and Hestia were reborn from Cronus's bellows (4), Cronus was imprisoned, and the generation of Olympians was born.

Another term which should be under investigation is cyclopia, also called cyclocephaly or synophthalmia, which refers to the condition of a foetus to fail to develop two orbits $(5,8)$. As the term denotes, the origin of the word is rooted in the Cyclopes, a group of one-eyed giants (3). They had a single large eye in the middle of their forehead, and they were the gods of thunder and lightning. The three Cyclopes were saved and freed by Zeus and, as a sign of gratitude, they produced a lightning bolt for their saviour, Arges added brightness, Brontes added thunder, while Steropes added lightning (9).

The Electra complex is a psychological concept where a daughter distains her mother and is more affectionate towards her father, in other words it is a competition with the mother for the posses- sion of the father. The concept can be put down to mythological events. Clytemnestra was the sister of Helen, daughter of Zeus, and the woman Leda, a princess of Sparta before she married Agamemnon, and queen of Mycenae. Clytemnestra and Agamemnon had three children: Iphigenia, Orestes, and Electra (4). According to some other accounts, the two had four children, Chrysothemis being another daughter (1). At a relatively young age Iphigenia was sacrificed by Agamemnon. Following the Trojan War, Agamemnon returned with a woman as his slave, Cassandra, princess of Troy. During Agamemnon's absence, however, Clytemnestra developed a relationship with Aegisthus, Agamemnon's cousin and archenemy. Agamemnon was murdered by the two lovers. Orestes and Electra disagreed with their mother's decision and sought revenge. There are various versions of the story belonging to Aeschylus, Euripides, or Sophocles, but they all come down to the two brothers planning and carrying out the murder of Clytemnestra and Aegisthus.

The first description of the disease entity called hebephrenia is attributed to Ewald Hecker (1, 10). In 1871 he defined hebephrenia as a disorder with a very specific and predictable course always occurring between the ages of 18 and 22. A type of schizophrenia, hebephrenia, or hebephrenic schizophrenia, has symptoms such as disorganised behaviours and thoughts, short-lasting delusions and hallucinations, disorganised speech. Zeus had several children with his wife, Hera, among whom there were Ares, Hebe, Eileithyia, and Hephaestus (3). According to other sources, Eris was born to Hera without the help of Zeus (9), that is parthenogenetical1y. Ares was the god of war, whose only delight was conflict, war, and violence. Hephaestus, on the other hand, was even more troublesome, he was lame and so unappealing that his mother flung him from Mount Olympus. Nevertheless, Hebe, a cupbearer to the gods and the goddess 
of eternal youth, was the least demanding of the children. Hebe was responsible for readying her mother's horse when she went out, she looked after her siblings, and handled the other household chores. She was also in charge of preparations and served the other gods at their banquets. Eventually, she married Heracles and escaped from her former chore-filled life (1). If we consider that Hebe's marriage to Heracles is a type of victory happening in youth, the concept of hebephrenia, the condition that occurs at the end of puberty, is fully explained.

Nyx (Night) and Erebus (Darkness) had two children, Hemera (Day), and a corresponding brother, Aither, who personified brightness. The name of Hemera gave birth to the word ephemeral to refer to something short-lasting. In medicine, however, hemeralopia refers to a condition in which vision is impaired in bright light, in other words day blindness (1).

Asclepius, the god of medicine, had three daughters: Hygieia, Panacea, and Iaso (according to some sources, there were seven daughters). Hygieia, the goddess of health and hygiene (11), is often represented dressed in a long robe, and feeding a serpent from a cup. She had the power to ward off pestilence and to promote health. The name of the goddess gave rise to the word hygiene to mean, among others, the science of the establishment and maintenance of health. Her name is also mentioned in the Hippocratic Oath "I swear by Apollo Healer, by Asclepius, by Hygieia, by Panacea, and by all the gods and goddesses, making them my witnesses, that I will carry out, according to my ability and judgment, this oath and this indenture".

Apart from her children with her brother Erebus, Nyx (Night) parthenogenetically produced Momus, Thanatos, Hypnos, the Moirae, and Nemesis (12). The children of Nyx who lived in a subterranean place and emerged at night were Hypnos (Sleep) and Thanatos (Death). While Hypnos was kind to mortals, his brother Thanatos was rather the opposite and was hateful even to the immortal gods. Hypnos fell in love with Endymion and caused him to sleep with wide open eyes. Hypnos had the power to induce a state of lack of awareness and animation upon both mortals and immortals. James Braid, a Scottish surgeon and natural philosopher, is considered to be the father of hypnosis and the one who coined the term hypnosis from the name of the Greek mythological figure, and a whole string of words related to the concept: hypnology, hypnoid, hypnotise, hypnotic, or hypnotism. Hypnos became to be regarded as the God of Anesthesia (13).

We previously discussed the case of Aphrodite as the one whose name gave us the word aphrodisiac. Nevertheless, Aphrodite is also responsible for another term that is used in medicine, i.e., hermaphrodite. Aphrodite does not get the whole credit for this term, half of it is the contribution of Hermes. Hermaphroditus was the child of Aphrodite and Hermes (4), the son of Zeus and the nymph Maia, who had female breasts and male genitals, thus, the term to describe anyone with the reproductive organs of both sexes. According to mythology, the boy had not been born a hermaphrodite, it was one of the nymphs, Salmacis, mesmerised by his handsomeness, who followed him into the lake and embraced the boy while swimming (14). Thus, we also have the words of hermaphroditism or hermaphroditic.

A controversial word in terms of origin is $h y$ men. By controversy we mean that Hymenaios was the god of marriage, the son of Aphrodite and Dionysus (15), god of the grapes and alcohol, or that of Apollo and a muse. The name of the god was derived from the traditional wedding-cry with little meaning hymen o hymenaie or o hymen hymenaie, an invocation to a deity (14). According to another account, Hymenaios was a mortal who fell in love with an Athenian girl of noble origin (15). Whether the mortal or the god, the name gave us the term hymen, which 
in Greek simply meant membrane, and in contemporary use refers to the virginal membrane.

\section{Conclusion}

It is doubtless that Latin and Greek have shaped the Medical English we use today and continue to add terms to express discoveries, new realities, conditions, etc. On the other hand, Greek mythology is a vast resource of naming various diseases, substances, body parts. It is noteworthy that not only the names of gods and goddesses but also those of mortals depicted in mythological stories lie at the basis of terms commonly used by medical professionals. However, breaking the terms down, whether common or proper, into their constituents: roots, combining forms, and affixes, tracing the origins of roots, and justifying their use are fascinating processes.

\section{Conflict of interest}

None to declare.

\section{References}

1. Sentaro K. Medical Terms and Their Hidden Origins in Greek and Roman Mythology. BookBaby. 2019.

2. Mandhani A. Prostatic fascia and recovery of sexual function after radical prostatectomy: Is it a ,Veil of Aphrodite” or „Veil of mystery”!. Indian J Urol. 2009;25(1):146-8. DOI: 10.4103/0970-1591.45558

3. Taft M. (ed.) Greek Gods \& Goddesses, New York: Britannica Educational Publishing. 2014.

4. Albert, L. Greek Mythology. The Gods, Goddessess, and Heroes Handbook. From Aphrodite to Zeus, a Profile of Who's Who in Greek Mythology, Adams Media:
New York/London/ Toronto/ Sydney/ New Delhi. 2021.

5. Kucharz EJ. Medical eponyms of mythological origin. Acta Neophilologica. 2017; XIX (2):29-42. DOI: 10.31648/an.639

6. Hernigou P. Bone transplantation and tissue engineering, part I. Mythology, miracles and fantasy: from Chimera to the Miracle of the Black Leg of Saints Cosmas and Damian and the cock of John Hunter. International Orthopaedics. 2014;38:2631-8. DOI: 10.1007/s00264014-2511-y

7. Woodard RD. (ed.) The Cambridge Companion to Greek Mythology. Cambridge/ New York/ Melbourne/ Madrid/ Cape Town/ Singapore/ Sao Paulo/ Delhi: Cambridge University Press. 2007. DOI: 10.1017/ CCOL9780521845205

8. Sharma D, Yadav J, Garg E. Cyclopia syndrome. BMJ Case Rep. 2014;2014:bcr2014203535. Published 2014 Jun 9. DOI: 10.1136/bcr-2014-203535

9. Tanner R. Greek Mythology: Captivating Stories of the Ancient Olympians and Titans. CreateSpace Independent Publishing Platform. 2016.

10. Kraam A, Phillips P. Hebephrenia: a conceptual history. History of Psychiatry. 2012;23(4):387-403. DOI: 10.1177/0957154X11428416

11. Ökten Aİ. Mythology and Neurosurgery. World Neurosurg. 2016;90:315-21. DOI: 10.1016/j. wneu.2016.02.106

12. Dixon-Kennedy M. Encyclopedia of Greco-Roman Mythology. Santa Barbara, California/ Denver, Colorado/ Oxford, England: ABC-CLIO. 1998.

13. Bause GS. Hypnos, god of sleep. Anesthesiology. 2013;119(2):255. DOI: 10.1097/ ALN.0b013e3182a37c2f

14. Room A. Who's Who in Classical Mythology. New York: Gramercy Books. 2003.

15. Hard R. The Routledge Handbook of Greek Mythology. London/ New York: Routledge. 2004. DOI: $10.4324 / 9780203446331$ 